\title{
PITUITARY ADRENAL FUNCTION DURING CORTICOSTEROID WITHDRAWAL IN RHEUMATOID ARTHRITIS*
}

\author{
BY \\ J. R. DALY, A. B. MYLES, P. A. BACON, C. G. BEARDWELL $\dagger$, AND OSWALD SAVAGE \\ From the Department of Chemical Pathology, Charing Cross Hospital Medical School, \\ and the Kennedy Institute of Rheumatology, West London Hospital
}

It has been known for many years that administration of corticosteroids can cause atrophy of the adrenal glands (Ingle and Kendall, 1937), and that the severity of the atrophy is proportional to the duration of administration (Salassa, Bennett, Keating, and Sprague, 1953; Bennett, 1954). Kilby, Bennett, and Sprague (1957) described degranulation of the basophil cells of the pituitary which also correlated in severity with the duration and the amount of corticosteroid administered.

That these structural changes may be accompanied by severe functional inadequacy became apparent after the publication of reports of irreversible postoperative shock developing in patients who had previously received corticosteroids (Fraser, Preuss, and Bigford, 1952; Salassa and others, 1953; Bayliss, 1958; Winstone and Brooke, 1961). Salassa and others pointed out that only a small minority of patients at risk developed shock of this kind, and that it was impossible to foresee this complication in any individual patient. Winstone and Brooke regretted "the absence of a completely dependable test of adrenal reserve" which would enable those patients with pituitary-adrenal insufficiency to be detected.

The importance of reliable objective tests of pituitary-adrenal function in patients who are being considered for withdrawal of steroid therapy, or from whom steroid therapy has been recently withdrawn, is thus apparent.

Treadwell, Savage, Sever, and Copeman (1963) showed that, in a series of 41 patients who had received corticosteroids, less than half showed an adequate response to metyrapone, yet all showed a good response to ACTH. The metyrapone test, however, may not be very suitable in this context for it only indicates the response of the pituitary to the

\footnotetext{
*Requests for reprints should be addressed to Dr. Oswald Savage at the West London Hospital, London, W.6.

$\nmid$ Present address : Department of Medicine, Hammersmith Hospital, London, W.12.
}

stimulus of a low plasma cortisol by a "feed-back" mechanism (Liddle, Island, Lance, and Harris, 1958). Failure to respond to metyrapone might not mean inability to respond to stress. There is evidence that the "feed-back" mechanism differs from the stress response mechanism, and James and Landon (1964) have shown that, when the plasma cortisol is reduced to zero by means of an infusion of dexamethasone, it will still rise promptly in response to the stress of hypoglycaemia.

Amatruda, Hollingsworth, D'Esopo, Upton, and Bondy (1960) and Livanou, Ferriman, and James (1965) have used insulin-hypoglycaemia to assess the ability of the pituitary to respond to stress following corticosteroid therapy. This may be more useful than the metyrapone test in predicting the development of any serious pituitary-adrenal insufficiency.

This paper reports the results of pituitary-adrenal function tests performed during an attempt to withdraw corticosteroid therapy from a group of patients with rheumatoid arthritis.

\section{Material and Methods}

A series of 29 patients whose clinical details are published elsewhere (Bacon, Myles, Beardwell, Daly, and Savage, 1966) had pituitary-adrenal function tests performed (Table $\mathrm{I} \ddagger$, opposite). All were receiving prednisolone. and the corticosteroid doses cited in this paper refer to this preparation. Six (Cases 3, 15, 16, 23, 33, 34) received 40 units ACTH weekly in addition as it was thought that this might facilitate withdrawal.

The plasma cortisol level was determined several times for each patient during the period of corticosteroid dose reduction. The determination was carried out fluorimetrically (Spencer-Peet, Daly, and Smith, 1965). The normal range for this method is from 4 to $34 \mu \mathrm{g} . / 100 \mathrm{ml}$. (median value $12 \mu \mathrm{g} . / 100 \mathrm{ml}$.). All samples for plasma cortisol were taken between 10.15 and 10.45 a.m., unless

$\ddagger$ The Case Numbers in Table I correspond to those given in the paper by Bacon and others (1966). 
TABLE I

CLINICAL PARTICULARS OF 29 SUBJECTS

\begin{tabular}{|c|c|c|c|c|c|c|c|c|}
\hline $\begin{array}{l}\text { Case } \\
\text { No.* }\end{array}$ & Sex & $\begin{array}{c}\text { Age } \\
\text { (yrs) }\end{array}$ & $\begin{array}{c}\text { Duration } \\
\text { of Steroid } \\
\text { Therapy } \\
\text { (yrs) }\end{array}$ & $\begin{array}{c}\text { Total } \\
\text { Steroid } \\
\text { (g. prednisolone) }\end{array}$ & $\begin{array}{c}\text { Final Dose } \\
\text { of Steroid } \\
\text { (mg. } \\
\text { prednisolone) }\end{array}$ & $\begin{array}{l}\text { Weekly } \\
\text { ACTH }\end{array}$ & $\begin{array}{c}\text { Synacthen } \\
\text { Test }\end{array}$ & $\underset{\substack{\text { Insulin } \\
\text { Hypoglycaemia } \\
\text { Test }}}{ }$ \\
\hline $\begin{array}{r}1 \\
2 \\
3 \\
4 \\
5 \\
6 \\
7 \\
8 \\
10\end{array}$ & $\begin{array}{l}\mathbf{F} \\
\mathbf{M} \\
\mathbf{F} \\
\mathbf{F} \\
\mathbf{F} \\
\mathbf{M} \\
\mathbf{M} \\
\mathbf{F} \\
\mathbf{F}\end{array}$ & $\begin{array}{l}63 \\
58 \\
56 \\
23 \\
58 \\
57 \\
64 \\
59 \\
21\end{array}$ & $\begin{array}{c}14 \\
12 \\
5 \\
5 \\
5 \\
3 \frac{1}{2} \\
2 \frac{1}{2} \\
2 \\
1\end{array}$ & $\begin{array}{l}54 \\
46 \\
12 \cdot 7 \\
16 \\
9 \\
12 \\
7 \\
4 \\
2\end{array}$ & $\begin{array}{l}\mathbf{0} \\
0 \\
0 \\
0 \\
0 \\
0 \\
0 \\
0 \\
0\end{array}$ & $\begin{array}{c}\overline{-} \\
\overline{\text { Yes }} \\
\overline{-} \\
\overline{-} \\
\overline{-} \\
\overline{-}\end{array}$ & $\begin{array}{l}+ \\
+ \\
+ \\
0 \\
0 \\
+ \\
0 \\
0 \\
+\end{array}$ & $\begin{array}{l}+ \\
+ \\
+ \\
+ \\
+ \\
+ \\
+ \\
+ \\
+\end{array}$ \\
\hline $\begin{array}{l}11 \\
12 \\
14 \\
15 \\
16 \\
18 \\
19 \\
20 \\
21 \\
23 \\
24 \\
25 \\
28 \\
29 \\
30 \\
31 \\
32 \\
33 \\
34 \\
35\end{array}$ & $\begin{array}{l}\mathbf{M} \\
\mathbf{F} \\
\mathbf{M} \\
\mathbf{M} \\
\mathbf{F} \\
\mathbf{F} \\
\mathbf{F} \\
\mathbf{F} \\
\mathbf{F} \\
\mathbf{F} \\
\mathbf{F} \\
\mathbf{F} \\
\mathbf{M} \\
\mathbf{F} \\
\mathbf{M} \\
\mathbf{M} \\
\mathbf{F} \\
\mathbf{F} \\
\mathbf{F} \\
\mathbf{F}\end{array}$ & $\begin{array}{l}57 \\
45 \\
61 \\
42 \\
58 \\
50 \\
46 \\
47 \\
60 \\
53 \\
43 \\
46 \\
56 \\
37 \\
60 \\
44 \\
63 \\
54 \\
56 \\
42\end{array}$ & $\begin{array}{r}16 \\
16 \\
13 \\
12 \\
12 \\
10 \\
10 \\
8 \\
8 \\
7 \\
7 \\
7 \\
6 \frac{1}{2} \\
6 \\
6 \\
5 \\
5 \\
5 \\
5 \\
3\end{array}$ & $\begin{array}{l}64 \\
33 \\
32 \\
53 \\
48 \\
34 \\
38 \\
31 \\
28 \\
18 \\
24 \\
22 \\
18 \\
22 \\
23 \\
15 \\
12 \\
9 \\
6 \cdot 5 \\
8 \cdot 5\end{array}$ & $\begin{array}{r}4 \dagger \\
5 \\
4 \\
7 \\
6 \\
8 \\
4 \\
7 \\
7 \\
8 \\
10 \\
5 \\
6 \\
9 \\
5 \\
8 \\
3 \\
3 \\
2 \\
6\end{array}$ & $\begin{array}{c}- \\
\overline{-} \\
\text { Yes } \\
\text { Yes } \\
\overline{-} \\
\overline{-} \\
\overline{\text { Yes }} \\
\overline{-} \\
\overline{-} \\
\overline{-} \\
\overline{-} \\
\overline{\text { Yes }} \\
\text { Yes } \\
-\end{array}$ & $\begin{array}{l}- \\
+ \\
+ \\
+ \\
+ \\
+ \\
+ \\
+ \\
\pm \\
+ \\
\pm \\
\pm \\
+ \\
+ \\
+ \\
+ \\
+\end{array}$ & $\begin{array}{l}- \\
+ \\
+ \\
0 \\
+ \\
+ \\
+ \\
+ \\
0 \\
+ \\
0 \\
+ \\
+ \\
+ \\
0 \\
0 \\
+ \\
+ \\
+ \\
+\end{array}$ \\
\hline
\end{tabular}

*Case numbers are not consecutive in order to correlate with those cited in the companion paper by Bacon and others (1966).

†Case 11 had tests while on $5 \mathrm{mg}$. prednisolone.

otherwise stated, in order that results would be comparable both in terms of the normal diurnal variation and the time interval since the previous dose of prednisolone.

Adrenal responsiveness was tested in 25 of the patients by injecting $0 \cdot 25 \mathrm{mg}$. $\beta 1-24$ synthetic corticotrophin (Synacthen*), intramuscularly. No restriction was imposed on the patients' activity during this test. Plasma cortisol was determined immediately before and 30 minutes after the injection. Wood, Frankland, James, and Landon (1965) have reported the normal response to be a rise of at least $7.5 \mu \mathrm{g} . / 100 \mathrm{ml}$. 30 minutes after the injection. Greig, Browning, Boyle, and Maxwell (1966) found a minimum rise in normal subjects of $6 \cdot 8 \mu \mathrm{g} . / 100$ ml., but add that the 30 -minute value should exceed $19 \cdot 7 \mu \mathrm{g}$. As most of the patients reported in this paper were still on corticosteroids when the Synacthen tests were carried out, some of the pre-injection cortisol levels were very low. Consequently it was not thought appropriate to stipulate a minimum absolute value for the 30-minute cortisol level. On the basis of these reports a rise of at least $7 \mu \mathrm{g} . / 100 \mathrm{ml}$. at 30 minutes after Synacthen was thought to indicate a positive response. A rise of between 4 and $7 \mu \mathrm{g}$. was designated "impaired Synacthen test" and a rise of less than $4 \mu \mathrm{g}$. as a "negative Synacthen test".

Insulin hypoglycaemia was induced in nineteen subjects with positive or impaired Synacthen tests. Four

*Ciba Laboratories Ltd., Horsham, Sussex. additional subjects who had been completely withdrawn from corticosteroids had insulin-hypoglycaemia induced without having previously had Synacthen tests. They were assumed to have responsive adrenals as they showed resting plasma cortisol levels in the upper ranges of normal. One subject with a negative Synacthen test was subjected to hypoglycaemia.

Hypoglycaemia was induced in non-fasting subjects who remained at rest. Soluble insulin $0.1 \mathrm{unit} / \mathrm{kg}$. body weight was injected intravenously after blood had been withdrawn through an in-dwelling needle for glucose and cortisol determination. Samples were taken, every 15 minutes for glucose and every 30 minutes for cortisol, for 90 minutes.

Glucose was determined with glucose oxidase (Marks, 1959). On the basis of previous reports (Landon, Wynn, and James, 1963; Amatruda and others, 1960), it was decided that, if there was an inadequate cortisol response and at least two of the glucose samples were not below $30 \mathrm{mg}$. $/ 100 \mathrm{ml}$., the test would be repeated with a larger dose of insulin $(0 \cdot 15$ units $/ \mathrm{kg}$. or in one case 0.2 units).

We have taken a maximum rise of at least $7.0 \mu \mathrm{g} . / 100$ $\mathrm{ml}$. to be a normal response, as the stimulus of hypoglycaemia should be comparable to that of Synacthen on the adrenal, and this figure is in good agreement with the normal range described by Greenwood, Landon, and Stamp (1966). Patients with a rise of at least this degree will be described as having "positive hypoglycaemia tests". 
Urinary total 17-oxogenic steroids were measured in Case 11 by a periodate oxidation method (James and Caie, 1964).

\section{Results}

Plasma Cortisol.-Plasma cortisol values at different dose levels of prednisolone are shown in Fig. 1.

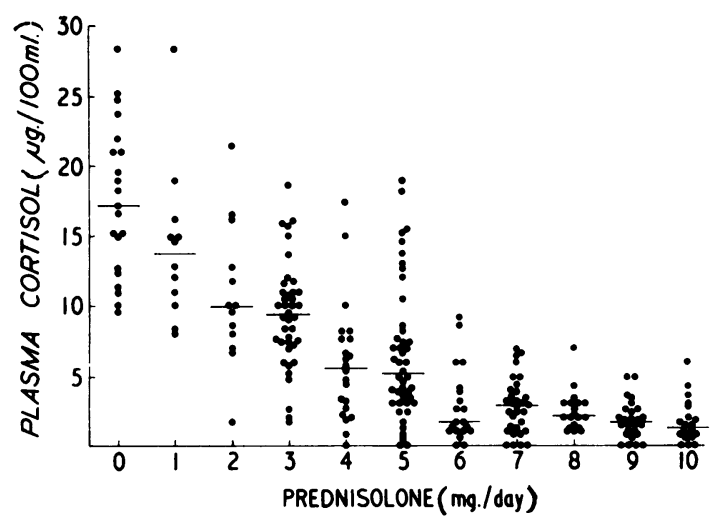

Fig. 1.-10.00 a.m. plasma cortisol levels at different daily prednisolone dosages. Horizontal dash represents median level.

As the dose of prednisolone was decreased the cortisol rose steadily, but the median value did not reach the normal range until the dose had been reduced to $5 \mathrm{mg}$. daily. At this level there were as many readings within the normal range as below it. At a $3 \mathrm{mg}$. daily dose, only three plasma cortisol readings were still below the normal range, and at $2 \mathrm{mg}$. daily only one. Individual patients' plasma cortisol levels were found to fluctuate widely at any given daily dose level below $5 \mathrm{mg}$., but they show little fluctuation above this dose.

There was no correlation between an individual's plasma cortisol level at any given dose and the duration of his corticosteroid therapy, and patients whose plasma cortisol remained sub-normal on doses below $5 \mathrm{mg}$. were not necessarily those who had been receiving corticosteroids the longest.

Synacthen Test.-In the 19 subjects who had not received weekly ACTH, the mean rise in plasma cortisol 30 minutes after the Synacthen injection was $9.7 \mu \mathrm{g} . / 100 \mathrm{ml}$. (range 0-24). Five subjects showed a negative response to Synacthen and two an impaired response. In those who showed a positive response the mean rise was $13.8 \mu \mathrm{g} . / 100 \mathrm{ml}$.

The mean rise in plasma cortisol in the six subjects who had received weekly ACTH was $14 \cdot 7 \mu \mathrm{g} . / 100$ $\mathrm{ml}$; if the one who showed a negative response is excluded, the mean is $17 \cdot 3 \mu \mathrm{g} . / 100 \mathrm{ml}$.
There was no correlation between the degree of response and the total dose or duration of corticosteroid therapy. Even after 5 years of therapy, fourteen of the subjects showed a positive response, 7 of them after 10 years.

Eight subjects showed positive responses at various times when receiving doses of more than $5 \mathrm{mg}$. daily, but all those who had negative or impaired Synacthen responses were still receiving at least $5 \mathrm{mg}$. daily at the time of testing.

There is clearly some correlation between the degree of response to Synacthen and the pre-injection plasma cortisol (Fig. 2). Although five subjects whose plasma cortisol levels were initially $4 \mu \mathrm{g} . / 100$ $\mathrm{ml}$. or less showed a positive response to Synacthen, no patient whose initial level was more than $3 \mu \mathrm{g}$. gave a negative or impaired response.

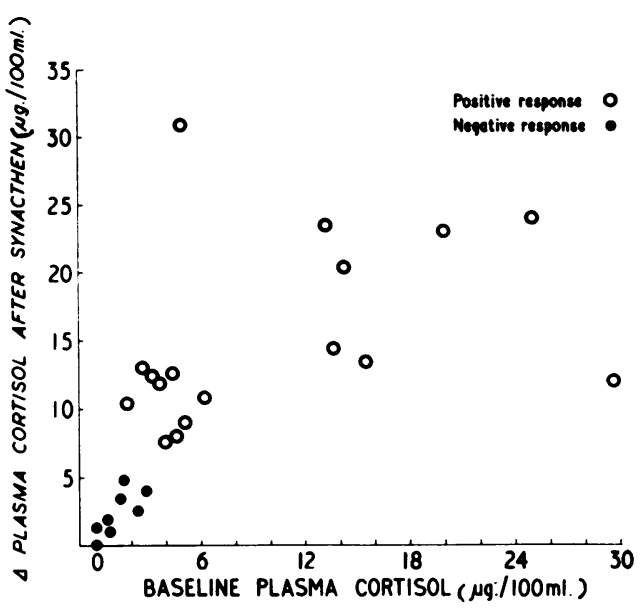

Fig. 2.-Rise $(\triangle)$ in plasma cortisol level $30 \mathrm{~min}$. after $0.25 \mathrm{mg}$ Synacthen plotted against pre-Synacthen plasma cortisol level. Solid circles represent negative or impaired responses.

Insulin Hypoglycaemia Test.-The mean maximum response to hypoglycaemia of the eighteen subjects in the group that had not received weekly ACTH was a rise in the plasma cortisol level of $12 \cdot 2 \mu \mathrm{g} . / 100 \mathrm{ml}$. (range 0 to $34 \cdot 2$ ). Three subjects showed a negative response with no detectable rise. Case 11 is considered separately.

The mean maximum rise in the five subjects tested who had had weekly ACTH was $10.7 \mu \mathrm{g} . / 100 \mathrm{ml}$. There was one impaired response (Case 3 ) in this group (maximum rise $4.6 \mu \mathrm{g} . / 100 \mathrm{ml}$.).

The shortest period of corticosteroid therapy after which any subject showed a subnormal response was 3 years (Case 35 ) (total dose $8 \cdot 5 \mathrm{~g}$.). There was no correlation between the degree of response and the duration of therapy. The largest response was 
obtained after 13 years' therapy (Case 14), and another patient gave a positive response after 16 years' therapy (Case 12).

The relation between the baseline cortisol level and the rise after insulin is shown in Fig. 3. Eight subjects with initial cortisol levels below $4 \mu \mathrm{g} . / 100$ $\mathrm{ml}$. gave positive responses.

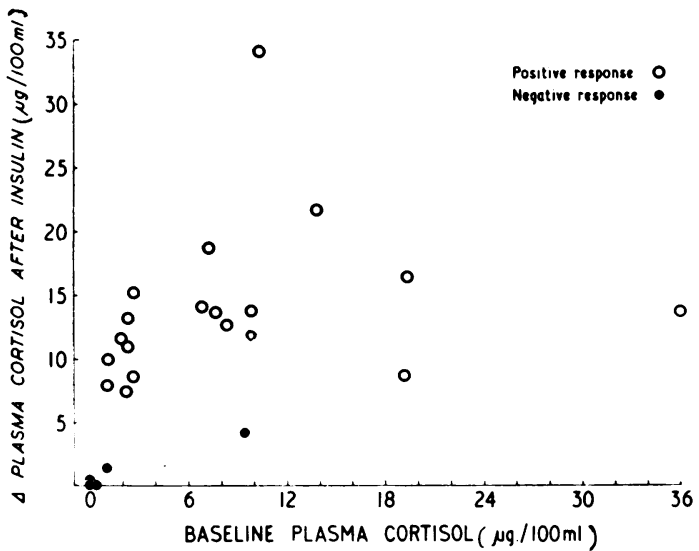

Fig. 3.- Maximum rise $(\triangle)$ in plasma cortisol level after insulin plotted against pre-insulin plasma cortisol level. Solid circles represent negative or impaired responses.

Case 3, however, failed to show a positive response despite a normal initial level. The test was carried out three times in this subject, whose results are shown in Table II.

TABLE II

RESULTS OF PITUITARY-ACRENAL FUNCTION TESTS IN CASE 3

This 56-year-old female had received weekly ACTH during withdrawal from steroid therapy. Despite normal baseline plasma cortisols and a good response to Synacthen her plasma cortisol did not rise normally during hypoglycaemia

\begin{tabular}{|c|c|c|c|c|}
\hline Date & Time & Test & $\begin{array}{c}\text { Blood } \\
\text { Glucose } \\
(\mathrm{mg} . / 100 \mathrm{ml} .)\end{array}$ & $\begin{array}{c}\text { Plasma } \\
\text { Cortisol } \\
(\mu \mathrm{g} . / 100 \mathrm{ml} .)\end{array}$ \\
\hline 25.1 .66 & $\begin{array}{l}10.00 \\
10.30\end{array}$ & Synacthen & 二 & $\begin{array}{l}29 \cdot 7 \\
41 \cdot 7\end{array}$ \\
\hline 24.2 .66 & $\begin{array}{r}9.30 \\
10.00 \\
10.15 \\
10.30 \\
10.45 \\
11.00\end{array}$ & $\begin{array}{l}\text { Insulin hypoglycaemia } \\
(0 \cdot 1 \mathrm{unit} / \mathrm{kg} .)\end{array}$ & $\begin{array}{l}80 \\
23 \\
37 \\
56 \\
53 \\
56\end{array}$ & $\begin{array}{r}11 \cdot 0 \\
9 \cdot 7 \\
14 \cdot 3 \\
13 \cdot 7\end{array}$ \\
\hline 19.4.66 & $\begin{array}{l}13.45 \\
14.15 \\
14.30 \\
14.45 \\
15.00 \\
15.15\end{array}$ & $\begin{array}{l}\text { Insulin hypoglycaemia } \\
(0.15 \mathrm{unit} / \mathrm{kg} .)\end{array}$ & $\begin{array}{l}75 \\
19 \\
36 \\
36 \\
39 \\
50\end{array}$ & $\begin{array}{r}9 \cdot 4 \\
10 \cdot 8 \\
12 \cdot 8 \\
13 \cdot 5\end{array}$ \\
\hline 14.6 .66 & 10.00 & Plasma cortisol & - & $22 \cdot 0$ \\
\hline 12.7 .66 & $\begin{array}{l}10.55 \\
11.25 \\
11.40 \\
11.55 \\
12.10 \\
12.25\end{array}$ & $\begin{array}{l}\text { Insulin hypoglycaemia } \\
(0.2 \text { units } / \mathrm{kg} .)\end{array}$ & $\begin{array}{l}60 \\
11 \\
21 \\
26 \\
32 \\
37 \\
\end{array}$ & $\begin{array}{l}27 \cdot 7 \\
26 \cdot 7 \\
28 \cdot 0 \\
26 \cdot 7\end{array}$ \\
\hline
\end{tabular}

A comparison between the response to Synacthen and the response to insulin is shown in Fig. 4, and the overall relation between test responses and the duration and total dosage of corticosteroids in Fig. 5.

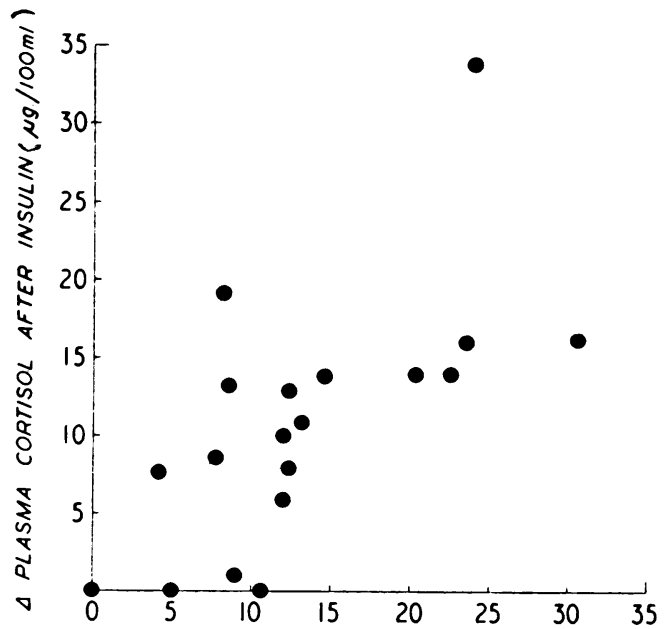

$\triangle$ PLASMA CORTISOL AFTER SYNACTHEN $(\mu \mathrm{g} . / 100 \mathrm{ml})$

Fig. 4.-Maximum rise $(\triangle)$ in plasma corti ol level in response to insulin hypoglycaemia plotted against rise $(\Lambda)$ in plasma cortisol level 30 min. after Synact' en.

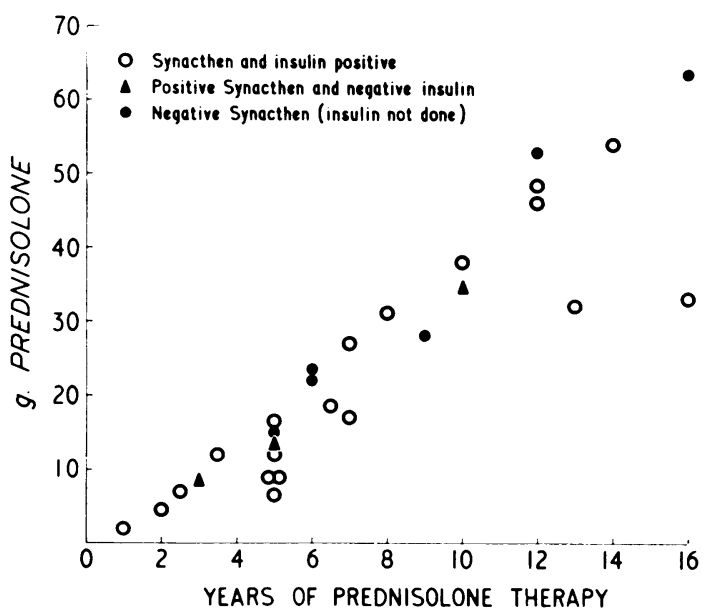

Fig. 5.-Results of pituitary-adrenal function tests in patients investigated after various periods and total doses of steroid therapy. Note: Case 29 shown as solid circle.

Case 11, a man who showed no response to Synacthen when he was receiving $5 \mathrm{mg}$. prednisolone daily, was admitted to the ward, ant the corticosteroid therapy was then stopped abruptly. Insulin hypoglycaemia evoked no response. Plasma cortisol levels were determined several times daily ard the Synacthen test was repeated, again with no response (Table III, overleaf). The total urinary 17-oxoger.ıc steroids were very low. Although the tests showed the pituitary-adrenal function to be 
TABLE III

RESULTS OF PITUITARY-ADRENAL FUNCTION TESTS IN CASE 11

After abrupt steroid withdrawal, this 58-year-old man at no time showed any symptoms other than slight joint pain, nor did his blood pressure fall

\begin{tabular}{|c|c|c|c|c|}
\hline Date & Time & Test & $\underset{\text { Glood }}{\text { Blucose }}$ & 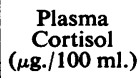 \\
\hline 13.4 .66 & $\begin{array}{l}10.00 \\
10.30\end{array}$ & Synacthen & - & $\begin{array}{l}\text { Nil } \\
1 \cdot 0\end{array}$ \\
\hline 14.4 .66 & 15.00 & Plasma cortisol & - & Nil \\
\hline 15.4 .66 & $\begin{array}{l}11.00 \\
11.30 \\
11.45 \\
12.00 \\
12.15 \\
12.30\end{array}$ & $\begin{array}{l}\text { Insulin hypoglycaemia } \\
(0 \cdot 1 \text { units } / \mathrm{kg} \text {. body } \\
\text { weight, } 6 \text { units total) }\end{array}$ & $\begin{array}{l}94 \\
\\
23 \\
33 \\
40 \\
60 \\
80\end{array}$ & $\begin{array}{l}\text { Nil } \\
\text { Nil } \\
\text { Nil } \\
\text { Nil }\end{array}$ \\
\hline $\begin{array}{c}17-18 . \\
4.66\end{array}$ & & $\begin{array}{l}\text { Urine } 17-O . G . S .= \\
2 \cdot 3 \text { mg. } / 24 \text { hrs }\end{array}$ & & \\
\hline 18.4 .66 & $\begin{array}{l}13.00 \\
24.00\end{array}$ & Plasma cortisol & & $\begin{array}{l}2 \cdot 1 \\
\text { Nil }\end{array}$ \\
\hline $\begin{array}{r}18-19 . \\
4.66\end{array}$ & & $\begin{array}{l}\text { Urine } 17 \text { O.G.S. }= \\
2 \cdot 1 \mathrm{mg} . / 24 \mathrm{hrs}\end{array}$ & & \\
\hline 19.4 .66 & $\begin{array}{l}18.00 \\
23.30\end{array}$ & Plasma cortisol & & $\begin{array}{l}1 \cdot 2 \\
1 \cdot 1\end{array}$ \\
\hline 20.4 .66 & $\begin{array}{l}06.00 \\
12.00 \\
24.00\end{array}$ & Plasma cortisol & & $\begin{array}{l}1 \cdot 6 \\
1.7 \\
1 \cdot 2\end{array}$ \\
\hline 21.4 .66 & $\begin{array}{l}06.00 \\
12.00 \\
20.00 \\
24.00\end{array}$ & Plasma cortisol & & $\begin{array}{l}1 \cdot 7 \\
2 \cdot 2 \\
1.9 \\
1.7\end{array}$ \\
\hline 22.4 .66 & $\begin{array}{l}12.00 \\
18.00 \\
24.00\end{array}$ & Plasma cortisol & & $\begin{array}{l}1.9 \\
1.7 \\
1.7\end{array}$ \\
\hline 23.4 .66 & 06.00 & Plasma cortisol & & $1 \cdot 4$ \\
\hline
\end{tabular}

markedly impaired, the patient showed no untoward symptoms apart from some joint pain. He was allowed up and about the ward without ill-effects and at no time did his blood pressure fall. During his insulin test his recovery from hypoglycaemia was no slower than that of other patients who had good cortisol responses, nor did he develop symptoms necessitating the administration of glucose.

It was not felt justifiable, however, to allow him out of hospital with so low a plasma cortisol level, and he was discharged on $4 \mathrm{mg}$. prednisolone daily. He was the only patient in this study who was maintained on corticosteroids because of pituitary-adrenal insufficiency and not because of arthritis.

\section{Discussion}

This study was carried out with a group of 29 patients with rheumatoid arthritis during their withdrawal from corticosteroid therapy. All but five had been on corticosteroids for at least 5 years, two as long as 16 years. Because of the recurrence of severe signs and symptoms of arthritis, withdrawal was not completed in the majority of patients (Bacon and others, 1966).
Synacthen and insulin-hypoglycaemia tests were performed when the attempt at withdrawal was completed, so that patients successfully withdrawn were tested while no longer receiving corticosteroids. Withdrawal failures, on the other hand, were tested at the lowest daily dose level achieved. In this study, therefore, besides considering pituitary-adrenal function in the light of the duration of corticosteroid therapy and the total dose administered, a third variable has been introduced, namely the daily dose of corticosteroid actually being received at the time of testing. In retrospect it has become clear that, had the tests been carried out on each subject several times, once at each of several different dose levels, then the effect of this additional variable could have been more precisely assessed.

Six subjects who were receiving 5 to $10 \mathrm{mg}$. prednisolone daily showed good responses to Synacthen and hypoglycaemia. All those who had negative or impaired Synacthen tests were receiving $5 \mathrm{mg}$. or more daily at the first time of testing because, with the exception of Case 11, none could be further withdrawn. Likewise, the three subjects (apart from Case 11) who showed negative insulin tests were receiving $6 \mathrm{mg}$. or more daily. Case 3, who showed an impaired response, was receiving only $2 \mathrm{mg}$. when first tested, and was twice re-tested after complete withdrawal; this patient was exceptional in this study in that she had normal resting plasma cortisol levels yet failed to respond to hypoglycaemia, although successfully withdrawn from corticosteroids. It is noteworthy that she was one of the six subjects who received ACTH weekly during withdrawal. All other subjects with normal baseline cortisol levels had positive Synacthen and insulin tests, as indeed did several with subnormal baseline cortisol levels.

Case 11 had his corticosteroid therapy stopped despite abnormal pituitary-adrenal function tests. He differed from Case 3, however, in that his plasma cortisol remained virtually at zero throughout the reduction of corticosteroids and after Synacthen as well as during hypoglycaemia. It is interesting that in a non-stressful environment it is possible to remain well and normotensive with an extremely low plasma cortisol level and an unresponsive adrenal.

The lack of correlation found in this study between both Synacthen and insulin tests and the total dose or duration of corticosteroid therapy contrasts markedly with the results of an earlier study from this unit in which metyrapone was used to test pituitary reserve (Treadwell and others, 1963). In that study there was clear correlation between pituitary responsiveness and duration of therapy. This suggests that the pituitary feed-back mechanism 
is damaged earlier in corticosteroid-treated patients than the mechanism by which the pituitary responds to stress. It may also account for the observation made frequently in this study that subjects with very low plasma cortisol levels nevertheless showed excellent responses to Synacthen and insulin (Figs 2 and 3).

It must be remembered in this connexion that pituitary-adrenal suppression has both acute and chronic aspects. The acute effect is the prompt depression of the plasma cortisol which results from each dose of corticosteroids with recovery after a few hours. Chronic suppression is manifested by the progressive failure of the plasma cortisol to recover after each dose. It may be that some of the patients whose baseline cortisol levels were very low, who yet showed good responses to Synacthen or hypoglycaemia, were in acute and not chronic suppression. Nevertheless, it appears that if a subject has a normal resting plasma cortisol level his feed-back mechanism must be intact, and hence that his stress mechanism must be intact also, as the former appears to be lost first. Our observations support this conclusion with the sole exception of Case 3 whose anomalous hypoglycaemia result has been discussed above.

The observation that the subjects who fail to respond to metyrapone may nevertheless respond to stress has also been made by Brinck-Johnsen, Solem, Brinck-Johnsen, and Ingvaldsen (1963), Kaplan (1963), and Amatruda, Hurst, and D'Esopo (1965).

Of the 29 subjects on whom pituitary-adrenal function tests were performed in our study, six showed adrenal unresponsiveness. Another four showed loss of pituitary response to stress whilst retaining their adrenal responsiveness to Synacthen. Unfortunately we were unable to assay plasma ACTH activity, so that pituitary responsiveness could be measured only indirectly. We were thus unable to determine whether those patients who had lost adrenal responsiveness had lost pituitary responsiveness also, as we were dependent on the former to assess the latter.

Graber, Ney, Nicholson, Island, and Liddle (1965) measured ACTH in corticosteroid-treated patients and found that the pituitary recovered first after corticosteroids had been withdrawn but that adrenal responsiveness lagged behind. It is not certain which gland failed first after starting corticosteroid therapy. The fact that three of our subjects had negative insulin but positive Synacthen tests suggests that pituitary failure may appear before adrenal unresponsiveness develops. Also no subject showed a negative Synacthen test after less than 5 years' therapy, but one case showed a negative insulin test after only 3 years.

The mean response to Synacthen in our subjects was a rise in plasma cortisol of $9 \cdot 7 \mu \mathrm{g} . / 100 \mathrm{ml}$. This is substantially below the mean of $16.5 \mu \mathrm{g}$. found in independent studies by Wood and others (1965) and Greig and others (1966) in normal subjects. However, if the definitely abnormal responses are eliminated from the calculation, the mean is $13.8 \mu \mathrm{g} . / 100 \mathrm{ml}$. This suggests the depression of the mean below normal is mainly due to the development of adrenal failure in a few of the subjects rather than to a general reduction in adrenal responsiveness throughout the entire corticosteroid-treated group.

Similarly the mean maximum rise in plasma cortisol after insulin was $12 \cdot 2 \mu \mathrm{g} . / 100 \mathrm{ml}$. If those who failed completely to respond are omitted, the mean becomes $14.8 \mu \mathrm{g}$. This is very close to the normal mean of $15.5 \mu \mathrm{g}$. found by Landon and others (1963), also suggesting that it is the total failures who depress the mean rather than a generalized lack of responsiveness in the whole group.

The effect of intermittent ACTH therapy during withdrawal remains uncertain. Six patients who received weekly ACTH showed the same percentage of positive and negative Synacthen tests, but an increased mean response to Synacthen and decreased mean response to hypoglycaemia. Further study is needed before it becomes apparent if this is significant.

The fact that nineteen out of 29 patients who had received prolonged corticosteroid therapy for from 1 to 16 years retained pituitary-adrenal responsiveness to stress as judged by insulin-hypoglycaemia is encouraging. Whilst it is not possible to assert definitely that the stress of hypoglycaemia can be compared to the stress of major surgery, a good cortisol response to hypoglycaemia should at least mean that the patient is capable of withstanding all day-to-day stresses without exogenous corticosteroids. In the majority of cases it seems that a normal plasma cortisol level is a sufficient indication of safety of withdrawal without the necessity for more elaborate tests. The possibility of regular measurement of the plasma cortisol certainly assists the physician in this situation, as it provides him with objective evidence of the state of the patient's pituitary-adrenal axis during withdrawal and, if normal, allows him to continue dose reduction with confidence. A subnormal plasma cortisol level at a dose of less than $5 \mathrm{mg}$. does not necessarily mean that withdrawal cannot be achieved, but it indicates that further pituitary-adrenal function tests may be useful.

\section{Summary}

(1) A series of 29 patients who had received longterm corticosteroids for rheumatoid arthritis was 
submitted to pituitary-adrenal function tests during withdrawal from corticosteroids.

(2) The plasma cortisol rose steadily as the corticosteroid dosage diminished. Below a dose of $5 \mathrm{mg}$. prednisolone daily more subjects had a plasma cortisol level above the lower limit of normal than below it.

(3) Ten of the 29 subjects showed impaired pituitaryadrenal responsiveness as tested by the Synacthen and insulin-hypoglycaemia tests.

(4) There was no direct correlation between duration of corticosteroid therapy and response to pituitary-adrenal function tests.

(5) With one exception, who showed abnormal response to insulin-hypoglycaemia, all subjects who had normal baseline plasma cortisol levels gave normal responses to the tests.

Ciba Laboratories have helped us with supplies of Synacthen. We gratefully acknowledge the skilled technical assistance of Mrs. M. Rake. This work was aided by grants from the Mathilda and Terence Kennedy Charitable Trust, the Arthritis and Rheumatism Council, and the Ministry of Health.

\section{REFERENCES}

Amatruda, T. T., Hollingsworth, D. R., D'Esopo, N. D., Upton, G. V., and Bondy, P. K. (1960). J. clin. Endocr., 20, 339 (A study of the mechanism of the steroid withdrawal syndrome. Evidence for integrity of the hypothalamic-pituitary-adrenal system).

- Hurst, M. M., and D'Esopo, N. D. (1965). Ibid., 25, 1207 (Certain endocrine and metabolic facets of the steroid withdrawal syndrome).

Bacon, P. A., Myles, A. B., Beardwell, C. G., Daly, J. R., and Savage, O. (1966). Lancet, 2, 935 (Corticosteroid withdrawal in rheumatoid arthritis).

Bayliss, R. I. S. (1958). Brit. med. J., 2, 935 (Surgical collapse during and after corticosteroid therapy).

Bennett, W. A. (1954). J. Bone Jt Surg., 36A, 867 (Histopathological alterations of adrenal and anterior pituitary glands in patients treated with cortisone).

Brinck-Johnsen, T., Solem, J. H., Brinck-Johnsen, K., and Ingvaldsen, P. (1963). Acta med. scand., 173, 129 (The 17-hydroxycorticosteroid response to corticotrophin, metopiron and bactereal pyrogen).

Fraser, C. G. Preuss, F. S., and Bigford, W. D. (1952). J. Amer. med. Ass., 149, 1542 (Adrenal atrophy and irreversible shock associated with cortisone therapy).

Graber, A. L., Ney, R. L., Nicholson, W. E., Island, D. P., and Liddle, G. W. (1965). J. clin. Endocr., 25, 11 (Natural history of pituitary-adrenal recovery following long-term suppression with corticosteroids).
Greenwood, F. C., Landon, J., and Stamp, T. C. B. (1966). J. clin. Invest., 45, 429 (The plasma sugar, free fatty acid, cortisol, and growth hormone response to insulin. I. In control subjects).

Greig, W. R., Browning, M. C. K., Boyle, J. A., and Maxwell, J. D. (1966). J. Endocr., 34, 411 (Effect of the synthetic polypeptide $\beta^{1-24}$ (Synacthen) on adrenocortical function).

Ingle, D. J., and Kendall, E. C. (1937). Science, 86, 245 (Atrophy of the adrenal cortex of the rat produced by the administration of large amounts of cortin).

James, V. H. T., and Caie, E. (1964). J. clin. Endocr., 24, 180 (Determinations of urinary 17-hydroxycorticosteroids and their relation to cortisol secretion).

and Landon, J. (1964). In "Structure and Metabolism of Corticosteroids", ed. J. R. Pasqualini and M. F. Jayle, pp. 55-58, Academic Press, London and New York (Some observations on factors influencing the pituitary-adrenal axis in man).

Kaplan, N. M. (1963). J. clin. Endocr., 23, 953 (Assessment of pituitary ACTH secretory capacity with Metopirone: II. Comparison with other tests).

Kilby, R. A., Bennett, W. A., and Sprague, R. G. (1957). Amer. J. Path., 33, 155 (Anterior pituitary glands in patients treated with cortisone and corticotropin).

Landon, J., Wynn, V., and James, V. H. T. (1963). Endocr., 27, 183 (The adrenocortical response to insulin-induced hypoglycaemia).

Liddle, G. W., Island, D., Lance, E. M., and Harris, A. P: (1958). J. clin. Endocr., 18, 906 (Alterations of adrenal steroid patterns in man resulting from treatment with a chemical inhibitor of $11 \beta$ hydroxylation).

Livanou, T., Ferriman, D., and James, V. H. T. (1965). Proc. roy. Soc. Med., 58, 1013 (The response to stress after corticosteroid therapy).

Marks, V. (1959). Clin. chim. Acta., 4, 395 (An improved glucose-oxidase method for determining blood, C.S.F. and urine glucose levels).

Salassa, R. M., Bennett, W. A., Keating, F. R., and Sprague, R. G. (1953). J. Amer. med. Ass., 152, 1509 (Postoperative adrenal cortical insufficiency. Occurrence in patients previously treated with cortisone).

Spencer-Peet, J., Daly, J. R., and Smith, V. (1965). J. Endocr., 31, 235 (A simple method for improving the specificity of the fluorimetric determination of adrenal corticosteroids in human plasma).

Treadwell, B. L. J., Savage, O., Sever, E. D. and Copeman, W. S. C. (1963). Lancet, 1, 355 (Pituitaryadrenal function during corticosteroid therapy).

Winstone, N. E., and Brooke, B. N. (1961). Lancet, 1, 973 (Effects of steroid treatment on patients undergoing operation).

Wood, J. B., Frankland, A. W., James, V. H. T., and Landon, J. (1965). Lancet, 1, 243 (A rapid test of adrenocortical function). 
La fonction surréno-pituitaire au cours du sevrage cortisonique dans l'arthrite rhumatismale

\section{RÉSUMÉ}

(1) Une série de 29 malades ayant reçu un traitement prolongé par les corticostéroïdes pour arthrite rhumatismale fut soumise à des tests de la fonction surrénopituitaire pendant la période de sevrage.

(2) Le taux du cortisol plasmatique augmentait au fur et à mesure que le dosage des corticostéroïdes administrés diminuait. Au dessous d'une dose quotidienne de $5 \mathrm{mg}$. de prednisolone un plus grand nombre des sujets eurent un taux de cortisol plasmatique supérieur à la limite inférieure de la normale qu'inférieur à celle-ci.

(3) Dix sur les 29 sujets accusèrent une réactivité hypophyso-surrénale diminuée d'après les tests au Synacthen et d'hypoglycémie induite par l'insuline.

(4) Il n'y eut pas de corrélation directe entre la durée de la corticothérapie et la réponse aux tests d'exploration de la fonction hypophyso-surrénale.

(5) A une exception près, dans laquelle une réponse anormale d'hypoglycémie induite par l'insuline fut observée, tous les sujets ayant un taux de base de cortisol plasmatique normal présentèrent des résultats normaux aux tests précédents.
La función pituito-suprarrenal durante la interrupción del tratamiento corticosteroide en la artritis reumatoide

\section{SUMARIO}

(1) Una serie de 29 pacientes que habian recibido medicación prolongada con corticosteroides para artritis reumatoide fué sometida a pruebas de la función pituitosuprarrenal durante un período de interrupción del tratamiento.

(2) Las cifras del cortisol plasmático aumentaban a medida que la dosis corticosteroide disminuía. Cuando la dosis de prednisolona diaria se redujo a menos de $5 \mathrm{mg}$. la mayoría de los sujetos acusó un nivel del cortisol plasmático superior al límite inferior del normal y en la minoría este fué inferior.

(3) Diez de los 29 sujetos manifestaron una reactividad pituito-suprarrenal disminuida según los tests del Synacthen y de hipoglicemia inducida con insulina.

(4) No hubo correlación directa entre la duración de la corticoterapia y la respuesta a las pruebas de la función pituito-suprarrenal.

(5) Con una sola excepción, en la que se observó una respuesta anormal a la prueba de hipoglicemia inducida por insulina, todos los sujetos con cifras básicas normales de cortisol plasmático dieron una respuesta normal a los tests. 